\title{
Paradigma Pendidikan Islam dalam Pluralitas Masyarakat Barat
}

\section{NURWANTO}

Dosen di Pendidikan Agama Islam, Fakultas Agama Islam, Universitas Muhammadiyah Yogyakarta.

e-mail:nurwanto@umy.ac.id

$\begin{array}{ll}\text { Judul } & \text { : Islamic Education in Britain: New Pluralist Paradigms } \\ \text { Penulis } & \text { : Alison Scott-Baumann dan Sariya Cheruvalli-Contractor } \\ \text { Penerbit } & : \text { Bloomsbury Academic } \\ \text { Kota } & : \text { London } \\ \text { Tahun } & : 2015 \\ \text { Halaman } & : \mathrm{xv}^{+218} \\ \text { ISBN } & : 9781472581242\end{array}$

Buku Islamic Education in Britain ini lahir di saat yang tepat. Pencarian yang panjang tentang bagaimana Muslim Eropa terlibat dalam dinamika masyarakatnya yang plural baik dari aspek agama maupun budaya serta secara khusus bagaimana pendidikan Islam itu dikonstruksi, telah menjadi kajian, riset dan perdebatan. Tentu saja, buku ini berada pada konteks demikian, yakni sebagai ikhtiar akademis untuk mendudukkan secara rasional atas formasi pendidikan Islam yang sesuai untuk Muslim dan masyarakat Eropa.

Buku ini pada mulanya merupakan projek-projek riset yang terpisah, yakni: pertama, riset tentang training pemimpin Muslim di United Kingdom (UK) dari tahun 2008-2010. Kedua, riset tentang Muslimah dan Pendidikan Tinggi pada 2011. Ketiga, riset tentang Bahasa Arab di Pendidikan Tinggi dan Lembaga Keislaman pada 2012. Keempat, riset tentang makna penting partnership antara universitas-universitas di UK dengan lembaga-lembaga keislaman pada 2013. Selain itu, buku ini juga memberi informasi penting mengenai pemetaan wacana tentang Islamic studies dan Islamic education dalam spektrum pendekatan tradisional Islam dan pendekatan akademis di Eropa. Pada bagian akhir, penulis buku ini melontarkan sejumlah agenda revitalisasi 
pendidikan Islam dalam konteks masyarakat Eropa yang majemuk. Tulisan akhir ini justeru menjadi penting sebagai upaya untuk mengikat ide pokok dari keseluruhan temuan dan abstraksi atas riset-riset yang terpisah sebelumnya.

Hal penting lainnya adalah bahwa riset-riset yang disajikan dalam buku ini merupakan kolaborasi akademisi dari kampus-kampus dan sekolah-sekolah tinggi Islam (Islamic/Muslim College) di UK. Kedua penulis sekaligus penghimpunnya yakni Scott-Bauman dan Cheruballil-Contractor merupakan cermin dari partnership ini. Penulis yang pertama adalah akademisi wanita non-Muslim yang semula sebagai profesor di Pusat Kajian Masyarakat, Filsafat dan Kepercayaan di Universitas Derby, UK, sedangkan yang kedua adalah peneliti muslimat pada Pusat Kajian yang sama. Saat ini Scott-Bauman merupakan Profesor di Pusat Studi Islam SOAS, Universitas London. Hal menarik yang perlu disampaikan bahwa keduanya memiliki interest yang sama dan terlibat dalam sejumlah aktivitas akademis dan konferensi seperti BRAIS (British Association for Islamic Studies) yang berkantor di Universitas Edinburgh, Skotlandia. Asosiasi ini menghimpun akademisi dari berbagai latar belakang universitas, agama dan kepercayaan yang beragam, baik religius maupun rasionalis-sekuler, untuk mengkaji Islam dan masyarakat Muslim. Dengan latar belakang agama dan tradisi akademik Eropa, analisis keduanya tampak dalam buku ini, tentang bagaimana potret Islamic studies dan pendidikan Islam di Eropa itu dalam perspektif ideal dan empirik.

Pada bab awal, penulis mengkaji aspek-aspek yang berbeda tentang /slamic Theology (Teologi Islam) dan Islamic Studies. Teologi Islam pada umumnya diajarkan dan diskusikan di lembaga-lembaga keislaman termasuk sekolah tinggi Islam (Islamic College), seperti kajian tafsir, sunnah dan hadis, sufisme, tarikh, aqidah dan syariah. Dalam tingkat tertentu juga ada falsafah, sufisme dan kalam. Sementara itu, Islamic Studies sebagai bagian dari Religious Studies dikaji dan diperdebatkan di level universitas di UK. Hal yang kemudian dipaparkan adalah signifikansi keduanya pada konteks masyarakat Inggris yang majemuk. Selain itu, di antara keduanya-Teologi Islam dan Studi Islam — kerapkali diangkat dari pendekatan yang berbeda. Yang pertama cenderung dogmatik karena sumber kajiannya dianggap berasal dari teks yang suci sedangkan yang kedua menggunakan pendekatan sekular-rasional dan kritis melalui disiplin sosiologi, sejarah, antroplogi, linguistik, geografi dan politik. Terhadap dua pendekatan ini, kedua penulis menekankan kembali pada kebutuhan untuk merespons secara adil dan nyata tentang Inggris yang majemuk yang memerlukan keterbukaan dalam pengkajian Islam secara 
rasional. Tantangan nyata lainnya adalah bagaimana mengurangi prejudice dan meningkatkan pemahaman atas Islam. Kecurigaan sejumlah pihak bahwa Islamic studies di Universitas akan memicu kemunculan radikalisasi ${ }^{1}$ perlu diatasi melalui kajian Islam dalam pendekatan kritis yang seimbang dan konstruktif di tengah masyarakat Inggris yang majemuk.

Ide-ide besar di atas sebenarnya sejalan dengan perspektif dari akademisi lainnya, seperti Tariq Ramadan, Profesor Islamic Studies di Universitas Oxford, yang mengusung perlunya konsep 'partisipasi' dan 'kontribusi' Muslim atas dunia Eropa; bukan lagi sekedar mempersoalkan konsep 'integrasi' Muslim di Eropa, karena yang terakhir ini seolah-olah mendudukkan Muslim Eropa sebagai entitas baru yang perlu diakomodasi dalam dinamika sosial Eropa. Padahal, Muslim Eropa itu sendiri telah hadir dan bahkan sebagian besar generasi kedua dan ketiganya telah lahir dan besar dalam lokus Eropa. ${ }^{2}$ Secara spesifik, Abdullah Sahin, akademisi asal Turki yang kemudian berkhidmat di Markfield Institute of Higher Education (MIHE), sebuah lembaga riset yang didukung oleh Universitas Gloucestershire, berargumen perlunya pendekatan hermeneutis pendidikan Islam yang menjelajah kembali esensi pendidikan Islam secara normatif dalam berbagai konteks dan kemanusiaan secara luas, ${ }^{3}$ termasuk dinamika Eropa. Bila pandangan Ramadan dan Kahin ini dipinjam, maka menggairahkan kajian Islam di Eropa, bukan berarti meninggalkan apa yang dinamakan 'teks suci' keislaman. Tetapi, pemaknaan ulang terhadapnya sangat diperlukan terutama kebutuhan Muslim Eropa untuk ikut-serta berkontribusi secara proaktif menjadikan masyarakat Eropa dari berbagai latar belakang kepercayaan, agama dan etnis, dapat saling hormat dan mendukung antara satu dan yang lain serta melawan segala bentuk intoleransi dan terorisme.

Bab kedua secara khusus menggambarkan sistem lembaga pendidikan Islam d Inggris. Sebagian Muslim di Inggris belajar Islam sebagai sistem keyakinan dan perilaku bermula dari madrasah/maktab (4-11 tahun) yang berada di Masjid atau pusat komunitas Muslim. Secara khusus mereka belajar membaca Al-Quran dan cara membacanya (tajwid) serta akhlak keseharian. Muslim Pakistan atau Banglades cukup dominan di sana, sehingga bahasa pengantar yang digunakan pada umumnya adalah Bengali, Urdu atau Gujarati serta Arab. Pada usia 11-18 tahun ke atas, para pemuda Muslim dapat memperdalam Islam melalui-istilah lembaga Kristen — seminaries atau sekolah Islam seperti Darul Ulum (Suni Deobandi), Jami'ah (Suni Barelwi) dan Hauza (Syiah). Kedua penulis menginformasikan bahwa saat ini ada sekitar 138 sekolah Islam yang terdaftar di Departemen Pendidikan Inggris. Sebanyak 128 sekolah 
Islam tersebut murni swasta dan sisanya sekolah swasta keagamaan yang dibantu Negara. Lembaga-lembaga ini memiliki fokus untuk menghasilkan para pembimbing/guru agama Islam (alim-alimah), yang tentu saja dari aspek pemikiran dan figh dipengaruhi oleh aliran keislaman yang mengelolanya. Di samping itu, Muslim Inggris (18 tahun ke atas) dapat pula mengikuti berbagai kursus-kurus keislaman yang tersedia secara online atau kajian keislaman yang ditawarkan bagi Muslim secara personal untuk memperdalam Islam. Selanjutnya tersedia pula kampus-kampus di UK yang menawarkan Islamic Studies seperti SOAS (Universitas London), Universitas Cardiff, Universitas Cambridge, Universitas Oxford dan Universitas Exeter-untuk menyebut beberapa saja. Pendekatan studi Islam di kampus-kampus ini bersifat lintas disiplin, rasional dan kritis yang tentu saja berbeda dengan pendekatan yang ada di madrasah atau sekolah Islam pada umumnya yang lebih menekankan aspek penghayatan keimanan (confessional approach). Pendekatan teologis keislaman yang lebih mendalam ditawarkan dalam program partnership seperti Cambridge Muslim College, Al-Mahdi Institute serta Program Master dan Doktor Keislaman di beberapa Sekolah Tinggi (College) yang dikerjasamakan dengan kampus seperti Universitas MiddleSex. Lembaga lainnya adalah kursus praktis untuk memperoleh sertifikat untuk menjadi pimpinan komunitas keagamaan seperti MIHE Chaplaincy Course dan Pengembangan Profesional Keagamaan yang ditawarkan oleh Faith Associate yang dikerjasamakan dengan Universitas East London bagi calon-calon imam dan guru madrasah. Penjelasan penulis buku ini menunjukkan bahwa lembaga pendidikan Muslim di Inggris sudah sedemikian berkembang.

Bab ketiga menelaah dinamika empirik mengenai peran imam atau pemimpin Muslim. Secara terminologis, istilah ini lazim digunakan untuk mereka yang memimpin ibadah salat terutama di masjid. Namun demikian, dalam pengertian kepemimpinan keagamaan dan sosial di Barat, konsep-konsep yang semakna yakni alim/ah, ustadz/ah dan mujtahid/ah, pada konteks tertentu sesuai dengan konsep chaplain (anggota lembaga keagamaan) dan faith adviser (penasihat kepercayaan/keagamaan). Pada prakteknya, peran imam tidak hanya memimpin sholat, proses pernikahan, pemakaman, melayani training keislaman dan memberikan pendapat tentang pandangan keyakinan dan fiqh, tetapi juga membangun komunikasi antar-komunitas dan kampus-kampus tentang pentingnya kohesi sosial. Keterlibatan secara nyata, seorang imam di Derby misalnya, ikut serta meyakinkan publik melalui telaah keislaman yang mendalam dan kampanye tentang ancaman radikalisme atas nama Islam. 
Inilah yang oleh kedua penulis buku ini dikatakan bahwa peran imam dalam komunitas telah menjadi 'penerjemah' Islam secara nyata untuk merespons persoalan-persoalan masyarakat Inggris secara luas. Keduanya berpendapat bahwa dalam dinamika Inggris, peran-peran keagamaan dan sosial pemimpin Islam (imam) tersebut telah mendorong pola baru mengenai 'otoritas' dan 'autentisitas' kepemimpinan Muslim, yang tentu saja berkaitan dengan syaratsyarat dan tahap-tahap yang perlu ditempuh untuk menghadirkannya dalam masyarakat yang dinamis dan kompleks dewasa ini. Di negara-negara lain, baik dengan penduduknya yang mayoritas atau minoritas Muslim, para pemimpin Muslim senyatanya juga dihadapkan pada kebutuhan untuk melakukan pencerahan keagamaan baik secara internal maupun eksternal bagi masyarakat luas. Di Indonesia misalnya, fatwa, keputusan dan ijtihad keagamaan secara luas oleh lembaga seperti Majelis Ulama Indonesia (MUI), Departemen Agama, Muhammadiyah dan Nahdhatul Ulama sangat diperlukan dan menjadi kompas perilaku keagamaan masyarakatnya.

Bab keempat membedah potensi, fakta dan harapan bahasa Arab untuk menjadi alat penting dalam dinamika Muslim Eropa. Pada bagian ini apa yang dipaparkan penulis dapat dibagi menjadi 4 (empat) aspek penting bahasa Arab sebagai, pertama, alat komunikasi; kedua, alat pengkajian Islam (Islamic studies); dan ketiga, alat integrasi sosial. Sebagaimana bahasa lainnya di dunia, bahasa Arab sebagai alat komunikasi memiliki unsur-unsur kebahasaan yang dapat dipelajari dan dikuasai, baik Muslim maupun non-Muslim. Namun demikian, dalam proses komunikasi, pemahaman atas bahasa dapat berkaitan dengan aspek-aspek simbolik, budaya, emosi, sosial dan politik. Penulis memberi contoh bahwa istilah 'jihad' dalam bahasa Arab mengandung pemahaman yang kompleks dan dapat memiliki pertimbangan nilai yang berbeda dalam konteks Muslim maupun non-Muslim. Selain itu, fakta menunjukkan bahwa 70\% Muslim di Inggris berasal dari Asia Selatan yang tidak berbahasa Arab sehingga lembaga pendidikan Islam memiliki kepentingan untuk mengajarkan bahasa ini untuk memahami Al-Quran dan ilmu keislaman lainnya terutama di Madrasah, sekolah Islam dan sekolah tinggi Islam. Sepanjang tahun 20122013, sistem kode mata kuliah oleh HESA (Higher Education Statistics Agency) merekam sekitar 280 mahasiswa S1 dan 5 mahasiswa pascasarjana yang mengambil mata kuliah yang berkaitan secara spesifik dengan bahasa Arab (terpisah dari studi Timur Tengah), yang tentu saja di luar program bahasa Arab yang tidak resmi. Sedangkan mereka yang mengambil mata kuliah yang judulnya berkaitan dengan kata 'bahasa Arab' di UK sebanyak 1.155 mahasiswa 
S1 dan 80 mahasiswa pascasarjana. Lebih lanjut dikatakan bahwa, sebagaimana riset British Council, bahasa Arab juga menjadi bahasa komunikasi penting di Eropa, setelah Spanyol, serta di atas Perancis dan China, yang diharapkan akan dapat menjadi sarana pemahaman dan integrasi sosial Eropa. Penulis menggunakan teori Ricoeur tentang bahasa sebagai 'paradigma bertoleransi' dan sarana 'mediasi' (conciliatory) melalui pemaknaan bahasa Arab ke dalam dinamika bahasa Inggris dan lainnya. Problematika linguistik dan pemaknaan sosial—yang dapat saja politis—sebenarnya tidak saja terjadi antar-bahasa yang berbeda. Dalam bahasa yang sama, pemaknaan antara orang yang berbeda juga menghasilkan interpretasi dan implikasi sosial yang berbeda seperti: persahabatan, pernikahan hingga manifesto politik. Level kebutuhan selanjutnya atas bahasa Arab, menurut kedua penulis, adalah di antaranya memahami kembali teks-teks keagamaan yang mendalam dan menjadi jembatan transformasi antar-dunia, keyakinan dan sekularitas, Timur dan Barat serta dunia Lama dan dunia Baru. Mereka menegaskan pentingnya 'pertukaran hermeneutis' (hermeneutical exchanges) dari berbagai manusia dan beragam latar belakang.

Bab kelima secara khusus menggambarkan potret historis mengenai peran sosial wanita Muslim pada awal abad Islam (7-8 M) dan Abad Pertengahan Muslim (9-13 M) dan selebihnya hingga pada kurun modern. Secara spesifik hal ini terutama berkaitan dengan arah dan keberpihakan pendidikan Islam kepada mereka. Penulis di antaranya menjelaskan bahwa Khadijah, isteri Nabi Muhammad, merupakan wanita Muslim sekaligus saudagar wanita pertama yang masuk Islam dan mempengaruhi perjalanan penyebaran Islam. Wanita lainnya adalah Aisyah (isteri muda Nabi) dan Fatimah (puteri Nabi) yang meskipun kepemimpinannya begitu penting tapi, dalam imajinasi Barat, mereka tidak muncul sebagai prototype Muslimah yang dinamis; atau bahkan kehadiran mereka tidak tersentuh. Tentu saja, sebagaimana ungkapan penulis, ini terjadi karena sebab-ganda, yakni, pertama, ideologi patriarkis dalam sebagian Muslim yang selanjutnya mempengaruhi teks-teks keislaman mengenai wanita; dan kedua, marginalisasi wanita melalui narasi populer tentang kecurigaan dan radikalisasi yang menggambarkan wanita Muslim sebagai sosok yang tidak lumrah seperti halnya wanita Barat pada umumnya. Dengan menggunakan perspektif Foucault tentang 'tidak ada pihak luar untuk berkuasa/berpengaruh' (no outside to power), penulis mengkritisi fenomena peming iran wanita melalui narasi sosial yang 'tidak berdaya' (wanita) atas dominasi laki-laki. Penguburan peran wanita Muslim seperti Begum Syah Jahan 
yang sebenarnya mendirikan masjid Syah Jahan di Woking pada 1889 di India terjadi, misalnya, karena website masjid itu justru hanya mengupas sosok Muslim (laki-laki) saja yang ikut serta mendirikan masjid itu. Pada konteks demikian, kedua penulis selanjutnya mengupas aspek normatif Islam dan memberi contoh tentang kiprah wanita Muslim dan keikutsertaannya dalam penguasaan dan penghafalan Al-Quran dan Al-Hadis, pendalaman teologi Islam serta keterlibatannya dalam transmisi pengetahuan sejak masa Nabi dan sahabatnya hingga abad pertengahan Muslim. Sketsa historis ini, oleh penulis, dijadikan sebagai justifikasi bahwa realitas Muslimah di Inggris yang belajar Islam melalui lembaga pendidikan Islam dan kampus di UK pada hakikatnya sejalan dengan ide dan praktek kesetaraan mereka tentang penguasaan pengetahuan dan partisipasi publik. Penulis akhirnya menyimpulkan bahwa wanita Muslim yang mengkaji Islam paling tidak karena dua kepentingan, yakni, pertama, mereka ingin memperdalam keyakinan Islam; dan/atau kedua, mereka hendak memastikan bahwa pendidikan Islam merupakan instrumen untuk bangkit dan berkontribusi, yang tidak hanya menjadikan mereka sebagai 'ibu', tetapi juga 'pemimpin agama', 'pekerja sosial' atau 'warga Inggris' pada saat bersamaan.

Riset terakhir yang dikaji tercantum dalam bab keenam. Bagian ini mengungkap alasan, dinamika dan arah kolaborasi beberapa universitas di UK dengan Sekolah (Tinggi) Islam. Di tengah iklim kompetisi kampus untuk memperebutkan sistem ranking dan akreditasi atas dasar 'kebebasan akademis' dan 'kompetisi pasar' (politik maupun ekonomi), pendekatan partnership ini merupakan gejala menarik. Secara sosial, hal ini dapat dilihat sebagai 'mediasi kultural' tentang pemahaman lintas-budaya dan agama di tengah tantangan dan tuduhan subversif dan radikalisme agama-terutama Islam setelah peristiwa 9/11 (pengeboman Twin Towers) dan 7/7 (teror di London). Lebih dari itu, kedua penulis mengidentifikasi alasan mengapa partnership itu dilakukan, di antaranya, pertama, sejumlah pihak seperti kampus, layanan pendidikan Muslim dan pihak Pemerintah tidak cukup menunjukkan kemampuan untuk memfasilitasi partnership. Kedua, pentingnya jaringan institusi untuk menjembatani pencarian solusi atas group prejudice dan pengabaian sosial-akademis di antara keduanya. Ketiga, meningkatkan kualitas kurikulum yang relevan dan inklusif dengan pluralitas masyarakat Inggris. Keempat, keperluan validasi oleh universitas di Inggris terhadap lembaga pendidikan Muslim terutama berkaitan dengan pengakuan lulusan di dunia kerja. Kelima, masukan pendanaan bagi universitas di UK karena Sekolah (Tinggi) Islam 
misalnya membayar sistem validasi yang dilakukan oleh universitas tersebut dan ini tentu saja mempengaruhi pola akses pendanaan di antara keduanya. Dewasa ini, kemunculan Muslim College di London atau Oxford dan MIHE dan, di sisi yang lain, Islamic Studies di Universitas Oxford, SOAS, Birmingham dan Exeter—untuk menyebut beberapa saja — merupakan bagian langsung atau tidak langsung dari model partnership itu. Jika kedua penulis berharap bahwa langkah ini merupakan upaya pengejawantahan paradigma pluralis dalam sistem pedagogis Muslim untuk merawat kemajemukan Britania Raya secara umum maka jawaban yang pasti tidak bisa dilihat dalam waktu yang pendek. Barangkali riset lanjutan diperlukan untuk melihat dan mengevaluasi tingkat keberhasilan atas harapan-harapan tersebut.

Sebagai catatan akhir, buku ini, dalam sejumlah aspek, mampu mendeskripsikan apa yang tengah berlangsung dalam sistem pendidikan Islam di UK dan, berikutnya, membacanya dengan kerangka tafsir sosial tentang fakta pluralitas masyarakat yang perlu dipertimbangkan hingga diakomodasi dalam sistem pendidikan Muslim itu sendiri. Kedua penulis telah berhasil membawa wacana pendidikan Muslim yang semula seolah-olah dari 'wilayah pinggiran' ke dalam 'wilayah sentral' perdebatan dalam dinamika pendidikan dan sistem sosial yang majemuk seperti Inggris atau Eropa pada umumnya. Namun, di sisi yang lain, sistem pendidikan Muslim itu sendiri juga pada akhirnya akan diuji dan perlu dievaluasi berkenaan dengan kemampuannya menjadi kompas pembangunan masyarakat yang beradab, egaliter dan toleran secara nyata sesuai dengan karakteristiknya, baik melalui out put sumber daya manusia, sains dan teknologi maupun budayanya.

\section{Catatan Akhir}

1 Riset tentang latar belakang studi Perguruan Tinggi dari beberapa (terduga) teroris, misalnya oleh Gambetta, D. dan Steffen Hertog, Engineers of Jihad: The Curious Connection between Violent Extremism and Education. New Jersey: Princeton University Press, 2016.

2 Tariq Ramadan, What I Believe. Oxford: Oxford University Press, 2010, h. 5-6.

3 Abdullah Sahin, New Directions in Islamic Education: Pedagogy and Identity Formation. Leicestershire: Kube Publishing Ltd., 2013, h. 3. 